are being studied, each involving a combination of three different forms of protection. For temperatures less than $540^{\circ} \mathrm{C}$, insulation would be provided by panels of titanium facing covering an insulating honeycomb. In the $540^{\circ} \mathrm{C}$ to $980^{\circ} \mathrm{C}$ range, the same arrangement would be used, this time using a superalloy known as Inconel 617.

The most significant change would be in the high temperature panels, where heat shielding would be achieved by panels of reinforced carbon/carbon, up to three feet square. Various insulating materials would be placed between the shielding and the aluminium surface. The panels would be mechanically attached to the shuttle, avoiding the bonding problem associated with the ceramic tiles. Carbon/carbon is already used in limited quantities for the nose-cap and the leading edges of the shuttle's wings.

But however the new systems perform, there is still the problem of cost to be resolved. Moving to a new system would be expensive, and NASA may not be able to afford a switch.

David Dickson

\section{Nuclear reactor safety Go for Super-Sara}

\section{Brussels}

The months of deliberation in Brussels on the future of the Super-Sara project have ended with a decision to press ahead on the lines of the Commission's original proposal. The EEC's joint research centre at Ispra in Italy will now be able to start the second phase with funds totalling 50 million European Units of Account ( $£ 0.54=1$ EUA).

The Super-Sara project will use the experimental ESSOR reactor to study loss of coolant and other accidents in water reactors. More than 200 staff have been left in limbo since last November when the member states first began to hesitate about releasing the bulk of the project's money. In March 1980, 3.31 million EUA was granted for feasibility studies after the project was agreed in principle. But when it came to making available the 40 million EUA for the major part of the project, Germany and others began to have cold feet. The negotiations over the past six months left Germany as the only member state withholding agreement. Germany has now given way to pressure from its partners but has insisted that the project be kept below its budgetary ceiling.

However, the European Commission's initial cost projections have had to be raised since they were first made last year. Automatic salary increases and rising equipment costs mean that 64 million EUA needs to be set aside to take the project up to 1983 , when it is due to be reviewed.

It seems increasingly likely that it will overshoot its schedule by as much as two years.
Election in Israel \section{New deal for science?}

\section{Rehovot}

If, as expected, Labour Party leader Shimon Peres becomes Israel's next Prime Minister after the election in June, he will be the first man with a good grasp of science and technology to hold that office. Although not a scientist or engineer himself, Peres was responsible for initiating many large-scale research and development projects undertaken by the Ministry of Defence, where he served from 1952 to 1977 , becoming minister in 1974 .

These projects contributed substantially to Israel's military capabilities and also laid the groundwork for its sophisticated aircraft industry (with a turnover in 1980 of $\$ 500$ million) and for its rapidly developing electronics industry. Indeed, a very large percentage of Israeli exports based on local research (an estimated $\$ 1,000$ million last year) were spin-offs from defence research set in motion by Peres.

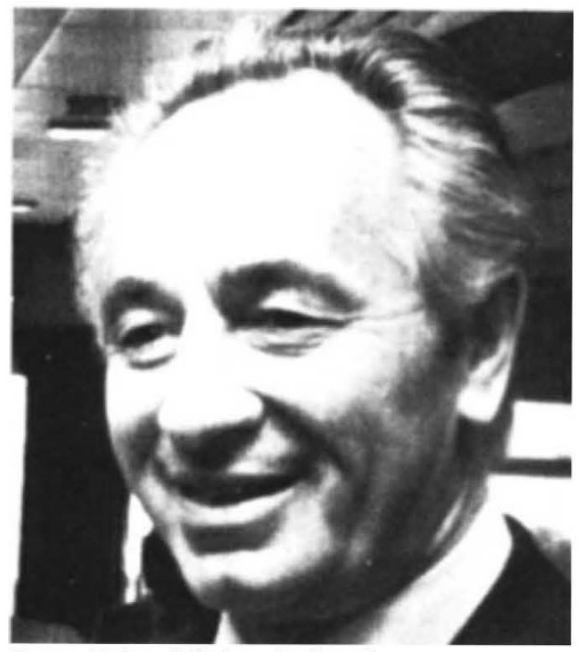

Peres, Prime Minister in June?

Peres has placed heavy emphasis on science-related projects in outlining the goals of a Labour-led government. There are plans for a huge "science city" in the Galilee, heavy government subsidies for energy research, a continuation of the recently inaugurated Mediterranean-Dead Sea Canal project for hydrological power and, significantly, the establishment of two nuclear power stations in the Negev.

Israel already has two research reactors, a 5-MW facility supplied by the United States and set up just south of Tel Aviv, and a more controversial $24-\mathrm{MW}$ reactor from France, located near the Negev town of Dimona. But, despite an absolute dependence on imported fossil fuel for the generation of electricity and the existence of the necessary nuclear technology, Israel still has no nuclear power stations.

This anomalous situation arises primarily because the United States, the most obvious supplier of such power stations, is prevented by the AntiProliferation Act from selling them until

\section{Kamikaze to Halley}

The European Space Agency (ESA) is hoping to enlist the help of the Soviet and Japanese space agencies in sending its Giotto spacecraft on a kamikaze mission to Halley's comet in 1986 . ESA would like to send Giotto to within $200 \mathrm{~km}$ of the comet's nucleus to observe molecules evaporating from it before they recombine or are interfered with by the solar wind. Initial plans had assumed a closest approach of $1,000 \mathrm{~km}$ because of the difficulties of pinpointing the precise position of the comet in advance and because of the risk to the spacecraft of cometary dust. If Giotto gets within 200 $\mathrm{km}$ of the comet it may manage a couple of hours of observation before being destroyed.

Such a close approach can only be made, however, with help from the Russian space agency which is also sending a spacecraft to the comet. The hope is that data from the Russian craft, due to arrive at the comet four days before Giotto, could provide precise details of the comet's whereabouts and allow last-minute corrections to Giotto's course. The Russian spacecraft itself will not be able to approach nearer than a few thousand kilometres to the comet nucleus because, unlike Giotto, it lacks a dust shield.

The Japanese spacc agency will also be sending a spacecraft - at $135 \mathrm{~kg}$ the smallest of the three - to photograph the comet in the hydrogen Lyman alpha line. The three space agencies are discussing how they might exchange data gleaned from their scparate missions, and next summer the three, together with the US National Aeronautics and Space Administration (NASA), will be meeting to discuss a collaborative project between all four agencies. Although NASA has no mission of its own to Halley's comet, it is organizing a "Halleywatch" which will make use of ground as well as space based observations.

Judy Redfearn

Israel signs the nuclear non-proliferation agreement and opens its nuclear facilities to inspection by the International Atomic Energy Agency.

It was only after Egypt signed this agreement in February that the United States agreed to provide that country with two nuclear power stations with a combined capacity of $2,000 \mathrm{MW}$. But Peres refuses to say whether a Labour-led government will do what all previous governments have refused to do, namely sign on the dotted line, or, if not, how he expects to get the reactors he proposes to place in the Negev.

Peres sees a close link between the country's economic development on the one hand and its scientific and technological development on the other. He accuses the present Begin government 